UDC 61:02-19/374-9

DOI https://doi.org/10.24919/2308-4863/44-3-33

\author{
Zhong TANG, \\ orcid.org/0000-0002-0082-4814 \\ Graduate Student at the Department of Fine Arts, Musicology and Cultural Studies \\ Sumy State Pedagogical University named after A. S. Makarenko \\ (Sumy,Ukraine) tanczun@gmail.com
}

\title{
MOTIVATIONAL COMPONENT OF FORMATION OF EMOTIONAL STABILITY IN MUSIC-PERFORMANCE ACTIVITY OF STUDENTS OF CHILDREN'S MUSIC SCHOOL
}

The study of the emotional stability of students of children's music school makes it possible to trace the relationship between this education and the quality of student performances in tests, exams, concerts, etc. Motivational and volitional component of emotional stability realizes the ability to personal growth, stability of emotional tone and favorable mood, the ability to emotional and volitional regulation, adequate to the situation motivational tension. The purpose of the article is to study the motivational and volitional component of the formation of emotional stability in the musical performance of students of children's music school; research of the term "emotional stability", its role and significance in musical performance; revealing the role of motivation in determining the emotional stability of DMS students. The methodological basis of the study are dialectical and systemic methodologies used in the field of psychological and pedagogical research. General scientific and logical methods of analysis, synthesis, induction and deduction, historical and comparative research of the problem are used. Novelty. The article is an attempt to explore the relationship between emotional stability in the musical performance of children's music school students and the motivational and volitional component. Practical meaning. The materials of the article can be used by teachers and psychologists of children's music schools, music studios to reduce the level of anxiety in music performance in students of instrumental and vocal departments. Conclusions. The positive manifestation of the motivational-volitional component realizes: the ability to full self-realization, personal growth with timely and adequate resolution of intrapersonal conflicts (value, motivational); relative stability of emotional tone and favorable mood, the ability to emotional and volitional regulation, adequate to the situation motivational tension. At the same time, students develop the ability to resist external influences, following their intentions and goals, improve the processes of mental self-government, self-regulation, self-control.

Key words: motivation, will, emotional stability, students of children's music school, musical-performing activity.

Чэнун ТАН, orcid.org/0000-0002-0082-4814 аспірант кафедри образотворчого мистецтва, музикознавства та культурології Сумського державного педагогічного університету імені А. С. Макаренка (Суми, Украӥна) tanczun@gmail.com

\section{МОТИВАЦЙНО-ВОЛЬОВИЙ КОМПОНЕНТ ФОРМУВАННЯ ЕМОЦІЙНОЇ СТІЙКОСТІ В МУЗИЧНО-ВИКОНАВСЬКІЙ ДІЯЛЬНОСТІ УЧНІВ ДИТЯЧОї МУЗИЧНОї ШКОЛИ}

\begin{abstract}
Актуальність. Дослідження емочійної стійкості учнів дитячої музичної иколи дає можливість простежити взаємозв'язок між таким утворенням та якістю учнівських виступів на заліках, іспитах, концертах тощо. Мотиваційно-вольовий компонент емоиійної стійкості реалізує здібність до особистісного зростання, стабільність емоційного тону й сприятливого настрою, здатність до емоційно-вольової регуляції, адекватну ситуації мотивачійну напруженість. Мета статті полягає в дослідженні мотивачійно-вольового компонента формування емоиійної стійкості в музично-виконавській діяльності учнів дитячої музичної школи; розгляді терміну «емоиійна стійкість», його ролі й значення в музично-виконавській діяльності; розкритті ролі мотивації у визначенні емоційної стійкості учнів дитячої музичної школи. Методологічну основу дослідження становлять діалектична й системна методології, щя застосовуються в галузі психолого-педагогічних досліджень. Використано загальнонаукові й логічні методи аналізу, синтезу, індукиї та дедукиії, історичного й компаративістського дослідження проблеми. Новизна. Стаття є спробою дослідити взаємозв'язок між емоційною стійкістю в музично-виконавській діяльності учнів дитячої музичної школи й мотиваційно-вольовим компонентом. Практичне значення. Матеріали статті можуть бути використані педагогами й психологами дитячих музичних шкіл, музичних студій для зниження рівня тривожності в музично-виконавській діяльності в учнів інструментальних $і$ вокальних відділень. Висновки. Позитивний прояв мотивачійно-вольового компонента реалізує: здатність до повноцінноі самореалізації, особистісного зростання зі своєчасним та адекватним вирішенням внутрішньоособистісних конфліктів (ціннісних, мотиваційних); відносну стабільність емоційного тону й сприятливого настрою; здібність до емоційно-вольової регуляції; адекватну ситуації мотивачійну напруженість. Водночас в учнів розвиваються здатності протистояти зовнішнім впливам, слідуючи своїм намірам і иілям, удосконалюються процеси психічного самоврядування, саморегулювання, самоконтролю.
\end{abstract}

Ключові слова: мотивація, воля, емочійна стійкість, учні дитячої музичної школи, музично-виконавська діяльність. 
Introduction. The problem of emotional stability in public speaking is one of the most important in music pedagogy and psychology. The ability to control oneself at the time of performance and to regulate the excitement of the stage is a mandatory task in the formation of fitness for performance.

The concert performance is the final stage of work on the piece of music. However, he often nullifies all the work done - both student and teacher. Thus, with pleasure and diligence in class, the student plays on stage with textual losses, with disruptions, without thinking about the musical image in the work. There is a contradiction between the student's desire to perform a piece of music at an exam, a concert and the inability to achieve this due to increased excitement.

Despite some elaboration of this topic, there is a shortage of scientific information about the nature and essence of stage excitement. Units of authors who raise this issue consider the emotional stability of public speech in conservatory students, aged 17-19 years. There are almost no studies on the problem of emotional stability in the performance of students of children's music schools, moreover, none of the authors considers the problem of emotional stability in music performance as a complex, ie, taking into account the individual personality of the student, the interaction of parents with the child, personal characteristics of his teacher.

Analysis of recent research and publications. The mechanisms of formation of emotional stability in ontogenesis, psychological methods of its diagnosis, environmental factors that favorably or adversely affect this personal characteristic, studied in the works of L. Badanin, V. Dolgova, L. Kulikov, E. Krupnik, V. Lupandin, V. Chudnovsky, L. Kandybovych, R. Lazarus, V. McDougall, V. Maryschuk, E. Milleryan, H. Murray, D. Rapoport, J. Reykovsky, O. Chebykin and others.

L.Abolin, Y. Babakhyan, B. Vardanyan, V. Vilyunas, L. Giessen, L. Grimak, D. Dodson, M. Dyachenko, P. Zilberman dealt with the issues of emotional stability of the personality as a subject of activity.

The objectives and tasks of the article are to study the motivational and volitional component of the formation of emotional stability in the musical performance of students of children's music school. Disclosure of the purpose of the article is realized through the study of the term "emotional stability", its role and significance in musical performance. The role of motivation in determining the emotional stability of DMS students is revealed.

The methodological basis of the study are dialectical and systemic methodologies used in the field of psychological and pedagogical research.
General scientific and logical methods of analysis, synthesis, induction and deduction, historical and comparative research of the problem are used.

Statement of basic materials. The structure of emotional stability is characterized by complexity due, on the one hand, the diversity of the structure of this mental education, on the other hand, a variety of factors that affect the process of its formation and manifestation.

Emotions (from the Latin emovere - to excite, excite) - a special class of mental processes and states (human and animal) associated with instincts, needs, motives, reflected in the form of direct experience (pleasure, joy, fear, etc.) significant for individual phenomena and situations that have a significant impact on the organization of his life. Accompanying almost any manifestation of the subject's activity, emotions are one of the main mechanisms of internal regulation of mental activity and behavior, aimed at meeting current needs.

The term "stability" comes from the adjective "stable", and means:

- first, "stable", "one that holds firmly, without hesitation, without falling";

- secondly, "not prone to fluctuations, constant, stable, solid". Stability indicates a person's personal resource as a complex highly organized system, its ability to maintain balance and stability of mental states in changing life circumstances (Ожегов, 2007).

In philosophy, the concept of stability is seen as a characteristic of a process or phenomenon associated with the functioning of a system, the specific properties of which, while remaining unchanged, distinguish them from others, and are called signs or symptoms. Non-specific properties of the object (process, phenomenon), on the contrary, may change, disappear or appear, but the quality of the object, its stability does not change. Stability characterizes the resistance of emotional states and processes to the destructive influences of internal and external conditions.

Investigating this phenomenon in children's music school students, we proceed from the definition of emotional stability as a willingness to resolve emotional situations in concert and performance activities. In the process of performing emotional stability reduces the negative impact of strong emotional influences, prevents extreme stress, helps to identify readiness for action in such tense situations. This is one of the psychological factors of reliability, efficiency and success of activities in an extreme environment, which is public speaking. It should be emphasized that emotional stability is a holistic characteristic of the individual, which ensures its willingness to withstand stress in difficult situations, and it includes, according to K. Levin, the 
ability to withstand excessive arousal and emotional stress arising from stressors, as well as the ability to maintain a high level of activation without interference. Emotional stability is formed simultaneously with the development of a holistic personality and depends on the type of human nervous system, its social experience, previously acquired behavioral skills, as well as the level of development of basic cognitive structures of the individual (Левин, 2001).

According to O. Chebykin, the same person in different conditions can show different levels of emotional stability. First of all, according to the author, it depends on the type of activity performed by him. If the subject has sufficient knowledge, skills and attitudes in professional work, external factors will have a much smaller negative impact than when such knowledge, skills and attitudes are absent (Чебыкин, 1992).

Of particular interest in this aspect is the study of S. Izyumova, who defines emotional stability as "a synthesis of qualities and personality traits that allow confidently, independently, without emotional stress to perform their professional activities with minimal errors for a long time" (Изюмова, 1978). Taking into account the above statement, it can be assumed that personal qualities are a necessary condition for both professional and emotional stability.

In musical performance, personal qualities play a decisive role, because thanks to them the student can weaken or neutralize the negative emotional factors that accompany the latter. Analysis of the state of the problem of emotional stability in the main areas of psychological science shows that it is provided by the optimal dynamic ratio of "components" of mental structures, which can be and personality, and consciousness, and activity.

Thus, emotional stability combines a range of abilities, a wide range of different levels of phenomena. In the analysis of emotional stability it is important to assess the effectiveness of adaptation processes, the integrative personality, maintaining the consistency of its basic functions, the stability of their implementation.

Emotional stability is largely determined by the strength of motives. Thus, the same person can show different degrees of the studied education depending on what motives motivate him to be active. By changing motivation, you can increase (or decrease) emotional stability. Motivation is determined by worldview. Emotional stability depends on a person's attitude to the phenomena of reality, on his individual philosophy. The same phenomenon, depending on its place in the scale of human values, has different effects on his mental state. Due to the different attitudes of man to the phenomena of reality, the psyche also plays the role of a selector of external influences selectively perceiving some and ignoring others.

A person's attitude to reality is determined primarily by the content and magnitude of his needs, the strength of the desire for achievement, selfimprovement, the level of aspirations, the importance of the goals he sets for himself, the role he would like to play in society. in their own strength.

This component is expressed in the conscious selfregulation of actions, bringing them into line with the requirements of the situation. In addition to the impact on external objects, human activity is directed to the organization of the activity itself. The essence of volitional behavior is the ability to subordinate their actions to the leading motives, long-term plans, tasks that arise from an adequate assessment of the situation. At the same time, lethargy is manifested in disorganization, which puts a person in a constant lack of time, which subsequently leads to chronic tension.

According to P. Fress and J. Piaget, an emotional situation can also occur with excessive motivation in relation to the real capabilities of man. Yes, the emotional situation depends on the contradictions between motivation and opportunities, causing different emotions. P. Fress (Фресc, Пиаже, 1973: 133-142) classified emotional situations, highlighting the psychophysiological features that affect a person's emotional response. His research allowed us to consider the problem of developing emotional stability of musicians-performers in terms of psychophysiological characteristics of man and emerging emotional situations in the process of professional performance of musicians, which are characterized by:

- novelty of the situation;

- unusual situation;

- suddenness of the situation;

- excessive motivation.

The musician, speaking in public, is always faced with the novelty and unpreparedness of the situation. He can't predict how the audience will react to his concert performance. The stage and the setting itself cause excitement and stress, as often the concert takes place in an unfamiliar place and is associated with communication with strangers. The peculiarity of the situation faced by the musician-performer is the uncertainty of the process of performing a musical work, how correctly the performed work will be presented to the audience. The musician-performer is always accompanied by the suddenness of the situation. Thus, in the process of performance there may be various unforeseen moments both on the part of the performer (feeling unwell) and on the part of the audience and 
the stage (lighting, mute, inadequate reaction of the audience, etc.). In addition, the musician's excessive motivation arises due to the discrepancy between the circumstances that inhibit his activities. Such situations can occur in three periods: before the performance (rehearsal period), during the performance and after. These include anxiety, fear, excessive arousal, accompanied by autonomic psychophysiological manifestations. Excessive motivation can manifest itself in social behavior, frustration, and conflicts that arise. Musicians often take part in competitions that involve competition with other performers. Reaction and excitement are characteristic in this case and are often out of balance, especially in those moments when the performance takes place in the presence of stronger opponents, causing a disorder of postural and mental functions of the body.

Of particular importance is the excessive motivation of the musician-performer in frustration, which always occurs when a physical, social and imaginary obstacle interferes with or interrupts the action aimed at achieving a goal. Old and new motivations are realized in all types of emotional reactions: aggression, retreat, regression. Conflict as a source of emotion affects the search for the right solution along with frustration, increasing motivation. Emotional situations that arise in the process of a musician's performance can be divided according to the level of sig- nificance: situations with a high degree of emotional reaction and low. The most significant are those situations that significantly affect the psychophysiological state of the musician, and at the same time the whole process of his performance. Important is the emotional response of the musician, which is a complex reaction, which involves both emotional and psychophysiological mechanisms of the body.

Conclusions. Thus, the positive manifestation of the motivational-volitional component realizes: the ability to full self-realization, personal growth with timely and adequate resolution of intrapersonal conflicts (value, motivational); relative stability of emotional tone and favorable mood, the ability to emotional and volitional regulation, adequate to the situation motivational tension. At the same time, students develop the ability to resist external influences, following their intentions and goals, improve the processes of mental self-government, self-regulation, self-control.

Prospects for further research in this area are to study the conditions of formation and development of stress and adaptive potential of emotional stability. We assume that there are close correlations between the level of emotional resilience and the effectiveness of overcoming emotional breakdowns, resilience in this case will indicate the severity of stress and adaptive capacity of the individual.

\section{BIBLIOGRAPHY}

1. Изюмова С. А. О физиологической природе связей между эмоциональной устойчивостью и свойствами нервной системы. Вопросы психологии. 1978. № 5. С. 128-133.

2. Левин К. Динамическая психология. Москва : Смысл, 2001. 572 с.

3. Ожегов С. И. Словарь русского языка : около 60000 слов и фразеологических оборотов. Москва : Оникс, 2001. 973 с.

4. Чебыкин А. Я. Эмоциональная регуляция учебно-познавательной деятельности. Одесса, 1992. 169 с.

5. Фресс П., Пиаже Ж. Экспериментальная психология. Москва : Прогресс, 1973. 344 с.

\section{REFERENCES}

1. Izyumova, S. A. (1978). O fiziologicheskoy prirode svyazey mezhdu emotsional'noy ustoychivost'yu i svoystvami nervnoy sistemy [On the physiological nature of connections between emotional stability and the properties of the nervous system]. Voprosy psikhologii [Psychology issues]. № 5. pp. 128-133. [in Russian].

2. Levin, K. (2001). Dinamicheskaya psikhologiya [Dynamic psychology]. Moskva : Smys1, 572. [in Russian].

3. Ozhegov, S. I. (2001). Slovar' russkogo yazika : okolo 60000 slov i frazeologicheskikh oborotov [Dictionary of the Russian language: about 60,000 words and phraseological phrases].Moskva : Oniks, 973. [in Russian].

4. Chebykin, A. YA. (1992). Emotsional'naya regulyatsiya uchebno-poznavatel'noy deyatel'nosti [Emotional regulation of educational and cognitive activity]. Odessa : [without edition], 169. [in Russian].

5. Fress, P., Piazhe, ZH. (1973). Eksperimental'naya psikhologiya [Experimental psychology]. Moskva : Progress, 344. [in Russian]. 